Зыкова, И. В., \& Киосе, М. И. (2021). Переключение социокоммуникативных регистров как параметр лингвистической креативности: Кинодискурс vs. дискурс детской литературы. Studia z Filologii Polskiej i Słowiańskiej, 56, Article 2384. https:// doi.org/10.11649/sfps.2384

Zykova, I. V., \& Kiose, M. I. (2021). Perekliuchenie sotsiokommunikativnykh registrov kak parametr lingvisticheskoŭ kreativnosti: Kinodiskurs vs. diskurs detskoı̌ literatury. Studia z Filologii Polskiej i Słowiańskiej, 56, Article 2384. https://doi.org/10.11649/sfps.2384

Ирина В. Зыкова (Институт языкознания РАН)

Мария И. Киосе (Московский государственный лингвистический университет)

\title{
Переключение социокоммуникативных регистров как параметр лингвистической креативности: Кинодискурс vs дискурс детской литературы ${ }^{1}$
}

\section{1. Вводные замечания}

В современной науке изучение лингвистической креативности уже не ограничивается констатацией используемых лингвистических приемов и описанием их гипотетической значимости для конструирования дискурса. Бо́льшую объяснительную силу приобретают статистические,

1 Исследование выполнено за счет гранта Российского научного фонда (проект №19-18-00040) в Институте языкознания РАН.

This is an Open Access article distributed under the terms of the Creative Commons Attribution 3.0 PL License (creativecommons.org/licenses/by/3.0/pl/), which permits redistribution, commercial and non-commercial, provided that the article is properly cited. (c) The Author(s) 2021.

Publisher: Institute of Slavic Studies, Polish Academy of Sciences

[Wydawca: Instytut Slawistyki Polskiej Akademii Nauk] 
экспериментальные и контрастивные исследования, которые позволяют установить дискурсивно-специфический характер лингвокреативности, ее роль в порождении и восприятии дискурса, относительную значимость используемых лингвокреативных приемов при построении того или иного типа дискурса (см., например, Jones, 2015; Musolff, 2019; Simpson, 2019). В настоящем исследовании развивается параметрический подход к анализу лингвистической креативности в контрастивно-дискурсивном аспекте, при котором изучению подвергается активность параметров всех языковых уровней разных типов дискурса, в данном случае, кинодискурса и дискурса детской литературы (см. подробнее в: Зыкова, 2019; Зыкова \& Киосе, 2020; Киосе, 2020). Параметрами лингвокреативности служат группы языковых показателей креативного использования разных уровней языковой системы, которые включают случаи намеренного нарушения литературной и дискурсивной нормы, средства (образной) выразительности и случаи интерференции языковых, межъязыковых и межсемиотических элементов.

В данной работе рассматривается лексический параметр «переключение социокоммуникативных регистров", демонстрирующий, во-первых, высокую, а во-вторых, отличающуюся активность в сопоставляемых дискурсах, и поэтому являющийся потенциально значимым для установления дискурсивно-специфического характера лингвокреативности. Цель работы - разработка методики разграничения креативных и некреативных проявлений параметра «переключение социокоммуникативных регистров» и установление технологий реализации лингвокреативности в контрастивном плане применительно к сопоставляемым дискурсам. Исследование проводилось на базе 44 популярных русскоязычных кинокомедий, вышедших с 1960-х по 2010 гг., и 160 русскоязычных произведений детской литературы (коротких рассказов, повестей, стихотворений) того же периода издания, предназначенных для детей дошкольного, младшего, среднего и старшего школьного возраста. Для демонстрации результатов проведенного контрастивно-дискурсивного исследования мы ограничимся в настоящей статье рассмотрением сходного по тематике и объему языкового материала в 55 тыс. знаков. В качестве своего рода образцов изучаемых дискурсов - кинодискурса и дискурса детской литературы - были отобраны две кинокомедии и четыре рассказа юмористической детской литературы 1950-1960-х гг., занимающие рейтинговые позиции в списках русскоязычных кинокомедий и произведений детской литературы. Это 
кинокомедии Семь нянек (Р. Быков) и Добро пожаловать, или Посторонним вход воспрещен (Э. Климов) и рассказы Райкины пленники (Ю. Сотник), А Воробьев стекло не выбивал (Ю. Яковлев), Дым в рюкзаке (В. Медведев) и Разноцветная история (В. Железников). Сопоставляемые дискурсы различаются по типу адресации, количеству и типам представленных коммуникативно-семиотических модальностей. Однако отобранные произведения объединяет общая дискурсивно-прагматическая установка на реализацию категории комического, установление проявлений которой (т. е. определение случаев комического и некомического) служит основанием для разграничения креативного и некреативного способов «переключения социокоммуникативных регистров».

\section{2. Методика и процедура анализа}

Для реализации поставленной цели разработки методики разграничения креативных и некреативных проявлений «переключения социокоммуникативных регистров» и последующего контрастивно-дискурсивного анализа необходимо:

1) уточнить понятие регистра применительно к описаниям социокоммуникативных ситуаций в дискурсе;

2) определить характеристики описания регистра, которые обнаруживаются в обоих типах дискурса, и провести их количественный анализ в рассматриваемом материале;

3) ориентируясь на общую прагматическую установку дискурсов, сформулировать единый критерий разграничения креативных и некреативных проявлений «переключения социокоммуникативных регистров»;

4) установить лингвокреативные технологии реализации параметра «переключение социокоммуникативных регистров» в контрастивном аспекте.

Как известно, понятие регистра к настоящему моменту не получило однозначного толкования. В литературоведении рассматриваются стилистические регистры, или подъязыки; так, это может быть трехточечная шкала регистров (высокий, просторечный и литературный с их разновидностями - Виноградов, 1981; Ревзина, 2014) или пятиточечная шкала 
(высокий официальный, официальный, нейтральный, неформальный, низкий неформальный - Quirk et al., 1989). Понятие стилистического регистра используется и в социолингвистике, где при изучении подъязыков социальных групп исследуется влияние факторов аккомодации речи к адресату или адресанту (Eckert, 2018; Giles \& Ogay, 2007). В то же время анализу подвергаются и коммуникативные регистры, под которыми понимаются типы ситуативных контекстов. Изначально предложенная Дж. Р. Ферсом (Firth, 1957) концепция коммуникативных регистров получила развитие в работах представителей социолингвистических школ (Biber \& Finegan, 1994; Eggins \& Martin, 1997; Gumperz, 1982; Ure \& Ellis, 1977), социокоммуникативных школ (Дементьев, 2006; Карасик, 2004; Dijk, 1993; Halliday, 1978; Halliday \& Hasan, 1980; Wodak, 1996) и социосемиотических школ (Andersen \& Boeriis, 2015; Leone, 2004; Matthiessen, 1993; Nöth, 1987). Разработаны и более частные концепции регистров, в которых объектами анализа становятся отдельные коммуникативные тактики и ходы (Жеребков, 1985; Золотова et al., 1998), разные типы адресации (Шубин, 1972), жанрово-стилистические типы (Biber, 1995; Oxford thesaurus of English, 2006).

При этом на выбор регистров могут оказывать воздействие и прагматические особенности дискурсивной коммуникации в целом (Gibbs \& Colston, 2020; Kiklewicz, 2017), например, интенциональность и адресация дискурса, которые определяют структуру коммуникативной ситуации и инвентарь языковых средств для ее представления. Такие дискурсивно обусловленные типы регистров мы будем называть социокоммуникативными. Под социокоммуникативными регистрами мы понимаем социальные подъязыки коммуникативного взаимодействия, выбор которых обусловлен прагматическими установками дискурса. Исходя из данного понимания и ориентируясь на материал исследования, в настоящей работе была принята следующая шкала социокоммуникативных регистров: (возвышенно-)официальный (институциональный, формальный), нейтрально-официальный, нейтрально-разговорный, неформальный (дружески-разговорный) и сниженный (сниженно-разговорный и сниженно-бытовой).

Объектом нашего анализа становятся переключения социокоммуникативных регистров, которые наблюдаются при смене характера коммуникативного взаимодействия и сопровождаются изменениями в формах социального общения при их передаче в дискурсе. При уста- 
новлении специфики этих переключений представляется возможным ориентироваться на изменения исходного регистра, являющегося основным (базовым) для того или иного типа дискурса, и на направления его изменения. В ходе проведенного контрастивного анализа кинодискурса и дискурса детской литературы мы установили, что исходными социокоммуникативными регистрами для обоих типов дискурса являются нейтрально-разговорный и нейтрально-официальный. Состав исходных регистров обусловлен общими типами социокоммуникативных установок дискурсов (сходные состав участников, характер общения, предметные области коммуникации). При этом переключения в обоих случаях осуществляются на (возвышенно-)официальный (институциональный, формальный) регистр как более высокий, неформальный (дружески-разговорный) и сниженный (сниженно-разговорный и сниженно-бытовой) регистры как более низкие.

Так, в приведенных далее фрагментах кинокомедии и рассказа детской художественной литературы обнаруживаются переключения на (возвышенно-)официальный регистр, на которые указывают фразы Bom заявляю офиииально и Подействуй на неё силой убеждения:

Полосухин: Вот заявляю официально, чтобы на вас не подумали (Р. Быков Семь нянек).

Криками не поможешь, - сказал Лёва. Возьми себя в руки и пойди поговори. Подействуй на неё силой убеждения (Ю. Сотник Райкины пленники).

Переключения на сниженный регистр продемонстрируем следующими фрагментами:

Митрофанова: Кыши! Иди гуляй! (Э. Климов Добро пожаловать, или Посторонним вход воспрещен)

- переключение на сниженно-разговорный регистр происходит посредством ввода предложений Кыш! Иди гуляй!

Торопливо скинув брюки, он в одних трусах отправился в коридор (Ю. Сотник Райкины пленники)

- переключение на сниженно-бытовой регистр осуществляется за счет выражения в одних трусах.

Решив, что это название мне пока ничем не грозит, я опять было затосковал о ботинках (В. Медведев Дым в рюкзаке) 
- переключение на неформальный, разговорный регистр совершается с помощью выражения мне пока ничем не грозит.

Согласно проведенному анализу, показателями таких переключений служат:

1) отдельные лексические единицы, например, переключения на регистр официального общения происходят благодаря вводу слов отцовский, непреклонность, едал, скупердяйство, и на разговорный и сниженный регистры - посредством использования таких слов, как Трепухи, двурушник, слушай, mьl, орет, запросто, ну;

2) словосочетания отбросы человечества, признайся чистосердечно, припали губами, скоропостижно скончались, больно страшный, где переключения осуществляются с помощью фразеологических единиц и выражений с разного рода интенсификаторами;

3) целые выражения типа Говорит Москва, Мне это ничем не грозит, Ты у меня получишь, Это у тебя не пройдет.

Решение проблемы разграничения креативных и некреативных случаев переключений социокоммуникативных регистров мы усматриваем в привлечении к анализу следующих дискурсивных характеристик:

1) социальных ролей участников коммуникации,

2) коммуникативных типов ситуаций,

3) социокоммуникативных форматов дискурса (например, нарративного, описательного, аргументативного, бытового и других форматов).

Переключения социокоммуникативных регистров «сигнализируют» о присутствии модификаций (искажений) в ролях участников, ситуации общения, формате дискурса, при этом одни модификации являются коммуникативно уместными, коммуникативно обусловленными и ожидаемыми, направленными главным образом на развитие сюжетной линии произведения; другие же являются коммуникативно неуместными, коммуникативно необусловленными и неожиданными, вызывающими явление, которое можно определить как социокоммуникативный диссонанс.

Социокоммуникативный диссонанс (как один из вариантов когнитивного диссонанса, см. Демьянков, 2011) мы соотносим с таким искажением в способах представления ролей, ситуации или формата дискурса (о возможностях социального искажения см. Ирисханова, 2016), при котором 
актуализируется прагматическая установка дискурса в целом. В нашем случае актуализация прагматической установки проявляется в демонстрации комического в кинодискурсе и дискурсе детской литературы. Возникновение социокоммуникативного диссонанса свидетельствует о том, что переключение регистров носит лингвокреативный характер. Продемонстрируем это на фрагменте из кинокомедии Э. Климова Добро пожаловать, или Посторонним вход воспрещен:

Докторша обращается к Косте Иночкину: И ты пожертвуешь своей редкой кровью?

Начальник пионерлагеря обращается к Косте Иночкину: Ты был для меня кровным врагом. А сейчас стал кровным братом (Э. Климов Добро пожаловать, или Посторонним вход воспрещен).

Здесь вымышленная (Костей) коммуникативная ситуация бытового дискурса - Костя Иночкин сдает свою кровь - представлена дискурсом формата возвышенно-официальных заявлений и обращений. Ввод последних не является коммуникативно обусловленным, нарушает логику ожидаемого коммуникативного взаимодействия между участниками коммуникации - мальчиком (Костей), врачом и начальником пионерлагеря, что вызывает социокоммуникативный диссонанс, который в свою очередь актуализирует прагматику комического. Комический эффект обеспечивается тем, что с помощью введения единиц возвышенно-официального регистра в ситуацию обыденного общения усиливается значимость и ценность поступка Кости, который в действительности является выдуманным. Таким образом, переключение социокоммуникативных регистров определяется в данном случае как лингвокреативное.

В результате исследования были установлены лингвокреативные технологии переключения социокоммуникативных регистров. Рассмотрим их подробнее в следующем подразделе статьи.

\section{3. Результаты исследования}

В ходе контрастивно-дискурсивного анализа мы определили особенности реализации переключений социокоммуникативных регистров с опорой на типы характеристик регистра и направления его переключения, а также лингвокреативные технологии переключения социокоммуникативных регистров в кинодискурсе и дискурсе детской литературы. 
На первом этапе было выявлено количество переключений социокоммуникативных регистров в сопоставляемых дискурсах, а именно, в двух кинокомедиях и четырех рассказах детской литературы. Общее количество переключений в кинодискурсе составило 58 случаев, а в дискурсе детской литературы - 365. Такие результаты свидетельствуют о значимости переключений регистров в создании динамики дискурса детской литературы, однако в отношении разграничения креативных и некреативных проявлений они менее показательны. Более высокое количество переключений в дискурсе детской литературы можно объяснить, во-первых, введением реплик автора (отсюда большее количество переключений на (возвышенно-)официальный регистр) и, во-вторых, отсутствием возможностей полимодальной репрезентации дискурса за счет, например, взгляда и жестов собеседников (отсюда большее количество переключений на разговорный регистр, в частности, реализуемых обращениями в разговорном регистре, например, Мишка, Райка).

Рассмотрим характеристики регистров и направления переключений. Так, мы обратили внимание на то, что частотность направлений переключений зависит в большей степени не от типа дискурса, а от особенностей социокоммуникативных установок в каждом конкретном произведении. Так, в кинокомедии Семь нянек обнаружено 46 случаев переключения регистров, из них 22 - на официальный регистр, 10 - на неформальный и 14 - на сниженно-разговорный, а в кинокомедии Добро пожаловать, или Посторонним вход воспрещен переключений на официальный регистр обнаружено только 2, а также 1 переключение - на неформальный и 9 - на сниженно-разговорный. Вариативность присутствует и в анализируемых рассказах детской литературы: так, в рассказе Ю. Сотника Райкины пленники обнаружено 50 случаев переключения на официальный регистр, 29 - на неформальный, 3 - на сниженно-разговорный и 8 - на бытовой, в рассказе Ю. Яковлева $А$ Воробьев стекло не выбивал также превалирует направление переключений на официальный регистр (23, 8 и 1, соответственно), а в рассказах В. Медведева Дым в рюкзаке и В. Железникова Разноиветная история - на разговорный регистр $(27,189,2$ и $3,21,1)$.

В ходе исследования все выявленные случаи переключения социокоммуникативных регистров были проанализированы с учетом социальных ролей участников, коммуникативных ситуаций или социоком- 
муникативных форматов дискурса. Покажем некоторые особенности их реализации.

Так, в рассказе В. Железникова Разноцветная история переключение нейтрально-разговорного социокоммуникативного регистра на разговорный происходит в результате смены социальных ролей. Рассмотрим пример:

- A ты всё равно зря тренируешься, - ответила Галя.

- Почему же? - осторожно спросил я.

- A потому, что с таким маленьким ростом не берут на вратарей.

Галя, когда злится, всегда напоминает о моём росте.

Это моё слабое место [...] Обо всём этом я, конечно, Гале не сказал, а только с издёвкой заметил:

- Не возьмут, говоришь? Три ха-ха! Много ты в этом понимаешь! (В. Железников Разноцветная история).

В данном фрагменте представлена ситуация общения брата с сестрой (социальные роли одного типа - детей в близкородственных отношениях). Саркастическое замечание Гали (А потому, что с таким маленьким ростом не берут на вратарей) стимулирует появление защитной реакции нападения у брата и, как результат, формирование социальной роли более опытного и демонстрирующего свое превосходство человека в Три ха-ха! Много ты в этом понимаешь!

В фрагменте кинокомедии Семь нянек режиссера Р. Быкова социокоммуникативный регистр меняется при смене коммуникативных типов ситуаций:

Радиоведущая: Начинаем урок утренней гимнастики (Р. Быков Семь нянек).

Переключение регистра на более формальный (официальный) посредством Начинаем урок утренней гимнастики обусловлено введением институциональной коммуникативной ситуации трансляции радиопередачи.

Смену социокоммуникативного формата дискурса проиллюстрируем следующим фрагментом рассказа Ю. Яковлева А Воробъев стекло не выбивал:

Мне жалко людей, которые рано перестали верить в сказки, разлюбили зверей и птии, забыли дорогу в детство. Они редко припадают к незамутненному родничку далекого детства, чтобы смыть копоть обыденности, золотую пыльиу корысти, разбедающую сердие, и туман самообольщения, 
который плотной пеленой застилает глаза (Ю. Яковлев А Воробьев стекло не выбивал).

Переключение на возвышенно-официальный регистр в смыть копоть обыденности, золотую пыльиу корысти, разбедающую сердие, и туман самообольщения происходит в результате смены формата дискурса с описательного дискурса на дискурс-рассуждение.

Как уже отмечалось выше, не все переключения являются лингвокреативными. В результате исследования были установлены лингвокреативные технологии переключения социокоммуникативных регистров, которые приводят к социокоммуникативному диссонансу при смене социальных ролей, коммуникативных ситуаций или социокоммуникативных форматов дискурса и служат целям создания комического эффекта в рассматриваемых произведениях.

Например, в приведенном ниже фрагменте переключение на официальный регистр (обращение к ребенку по фамилии, использование выражения признайся чистосердечно) оправдано социальной ролью директора школы (ситуация институционального общения директора школы с учеником) и поэтому не является демонстрацией лингвокреативности:

Директор ударил рукой по крупу бронзовой ломади. - Воробьев! Хоть раз в жизни признайся чистосердечно [...] (Ю. Яковлев А Воробьев стекло не выбивал).

Однако, смена социальной роли может актуализировать прагматическую установку дискурса в целом, заключающуюся в анализируемых кинокомедиях и рассказах в выражении комического. Так, в рассказе Ю. Сотника Райкины пленники коммуникация осуществляется между детьми, при этом отмечаются переключения на (возвышенно)-официальный регистр: здесь показателен выбор форм обращений между детьми, например, Борис и Раиса вместо Боря и Рая, использование в диалоге детей атрибутивных и глагольных единиц и выражений возвышенноофициального регистра, например, приложил руку к сердиу, испепелить взглядом, при моем появлении, ничтожная личность, представлял жалкое зрелище. Таким образом, возникает социокоммуникативный диссонанс, обусловленный рассогласованием социальных ролей ребенка и человека с более высоким социальным статусом / более опытного или взрослого, что вызывает комический эффект в дискурсе. 
Покажем на примере:

Рая появилась в дверях ванной, держа большую ложку, от которой шёл пар. - Боря, я тебя уже просила, а ты всё «некогда» и «некогда». Проверни мясо! Мясорубка тугая, я сама не могу, а мама ушла и велела приготовить котлеты. Боря уставился на неё, сдвинув светлые, чуть заметные брови:

- Слушайте, Раиса Петровна! Вам русским языком говорят: я тороплюсь, у меня поважнее дело, чем твои котлеты. Всё! Можете идти (Ю. Сотник Райкины пленники).

В данном фрагменте реализуется смена социальной роли Бори с семейной на роль начальника посредством ввода фразы Слушайте, Раиса Петровна!; социокоммуникативный диссонанс усиливается одновременным использованием сразу двух социальных ролей при выборе форм дейктических местоимений ты и $B$ для называния одного и того же участника коммуникации (сестры Раи) в Вам русским языком говорят: я тороплюсь, у меня поважнее дело, чем твои котлетьи, а также в выборе необычной предметной области для реализации социальной роли начальника (приготовление котлет).

Приведенный выше фрагмент иллюстрирует реализацию лингвокреативной технологии переключения социокоммуникативных регистров на уровне социальных ролей, вызывающей социокоммуникативный диссонанс.

Далее рассмотрим, как происходит социокоммуникативный диссонанс посредством лингвокреативной технологии переключения социокоммуникативных регистров на уровне коммуникативной ситуации.

В кинокомедии Семь нянек обнаруживаем эпизод, в котором трудный подросток, взятый из детской колонии на перевоспитание семью молодыми людьми - членами одной заводской бригады, выдумывает историю своего детства:

Афанасий Полосухин: Тяжелое у меня было детство. И отрочество. И юность. Не то что у писателя Льва Николаевича Толстого. Вот я щас на дядю Пашу посмотрел, батяню своего вспомнил (Р. Быков Семь нянек).

Прагматика комического в кинодискурсе достигается за счет рассогласования двух коммуникативных ситуаций комплексного типа придуманного детства Полосухина (обыденное) и событий трилогии Толстого (литературно-возвышенное). Социокоммуникативный диссонанс постепенно нарастает с перечислением Полосухиным названий частей 
трилогии (Л. Н. Толстой Детство, Отрочество, Юность), достигает своего пика при назывании имени, отчества и фамилии ее автора (Лев Николаевич Толстой) и сохраняется на высоком уровне с упоминанием мальчиком своих придуманных личных воспоминаний о пережитом детстве. Обращает на себя внимание сначала переключение на возвышенно-официальный социокоммуникативный регистр и далее - на сниженно-разговорный.

Социокоммуникативный диссонанс, возникающий посредством лингвокреативной технологии переключения социокоммуникативных регистров на уровне социокоммуникативных форматов дискурса, рассмотрим на примере фрагмента рассказа В. Медведева Дым в рюкзаке:

А я сидел безучастно на лестнице и переживал трагическую гибель своих любимых ботинок. Мои грустные мысли от нечего делать как-то сами собой складывались в сообщение, которое обычно печатают на последней странице газеты в чёрной рамочке. Эти сообщения называют, кажется, некрологами. «4 июля сего года, - сочинялось в моей голове, - скоропостижно скончались ботинки Валентина Громова (правый и левый). Они родились на обувной фабрике «Восход» и должны были прошагать по туристским тропам [...] не один десяток километров [...] Но глупая и преждевременная смерть вырвала их из наших рядов. Все, кто знал эти чудесные спортивные ботинки, сохранят о них светлую память [...] Выражаем своё искреннее соболезнование [...] их владельиу [...] Валентину Громову. Группа товарищей» (В. Медведев Дым в рюкзаке).

В приведенном примере комический эффект создается за счет того, что коммуникативная ситуация - мальчик съел свои кожаные ботинки и теперь переживает об этом - представлена не с помощью ожидаемого формата бытового дискурса и реализующего его нейтрально-разговорного регистра, а с помощью формата некролога и возвышенно-официального регистра, представленного выражениями скоропостижно скончались, преждевременная смерть вырвала ux из наших рядов. Данный регистр используется в дискурсивных форматах, описывающих человеческую трагедию и гибель любимого существа, здесь же он используется для представления «трагедии», произошедшей с ботинками.

Приведем некоторые данные по активности выявленных лингвокреативных технологий использования переключений социокоммуникативных регистров в двух типах дискурса. 
Для кинодискурса и дискурса детской литературы обнаружено одинаковое количество переключений, связанных со сменой формата дискурса (по 3 случая), при этом отличается активность лингвокреативных переключений в отношении социальных ролей и коммуникативных ситуаций. Наибольшую активность в кинодискурсе демонстрирует лингвокреативная технология переключения социокоммуникативных регистров на уровне коммуникативных ситуаций, вызывающая социокоммуникативный диссонанс (10 случаев). Предположительно, ее использование представляет эффективный способ стимулирования прагматики кинодискурса путем привлечения целых ситуаций без необходимости вводить новую сцену в кинофильм.

В дискурсе детской литературы, напротив, активность демонстрирует лингвокреативная технология переключения социокоммуникативных регистров на уровне социальных ролей (39 случаев), что, возможно, косвенно соотносится с когнитивными возможностями ребенка как адресата такого дискурса - ему легче придумать для себя или другого новую социальную роль, чем конструировать целую коммуникативную ситуацию. При этом новая роль в подавляющем большинстве случаев связана с использованием регистра более высокого порядка.

Также отметим сравнительно невысокую активность лингвокреативных технологий переключения социокоммуникативных регистров в дискурсе детской литературы относительно кинодискурса: процентное отношение таких примеров от общего количества случаев переключения регистра в дискурсе детской литературы составляет около $14 \%$, а в кинодискурсе это отношение выше и составляет около $30 \%$. Оставшиеся переключения соответствуют особенностям коммуникативного взаимодействия и поэтому не являются лингвокреативными. Такая ситуация свидетельствует о том, что в целом по относительным показателям (относительно общего количества переключений) лингвокреативный потенциал данного параметра в кинодискурсе в два раза выше, чем в дискурсе детской литературе, однако по абсолютным показателям активность данного параметра в три раза выше в дискурсе детской литературы.

Представляется необходимым установить, являются ли обнаруженные закономерности распределения креативных и некреативных случаев переключений зависимыми от типа дискурса или же сходное распределение обнаруживается в обоих дискурсах. Для статистического подтвержде- 
ния/опровержения дискурс-специфического характера распределения креативных и некреативных переключений социокоммуникативных регистров в кинодискурсе и дискурсе детской литературы проведен тест по установлению значимости данных проявлений в парных выборках (с применением t-критерия Стьюдента для парных выборок). В качестве нулевой гипотезы принято положение об отсутствии дискурс-специфического характера распределения креативных и некреативных переключений социокоммуникативных регистров в кинодискурсе и дискурсе детской литературы. Для значений общего количества переключений и количества лингвокреативных переключений равных 58 и 17 в кинодискурсе и 365 и 51 в дискурсе детской литературы, значение t-критерия Стьюдента составило 1.3 при $\mathrm{p}=0.417$. Высокое значение $\mathrm{p}$-вероятности ошибки первого рода (ошибки отвергнуть нулевую гипотезу об отсутствии дискурс-специфического характера распределения) не позволяет утверждать наличие сходного характера распределения. Таким образом, распределение креативных и некреативных переключений определяется скорее именно типом дискурса, а не общими характеристиками дискурса в целом.

\section{4. Выводы и заключение}

В исследовании разработана методика разграничения креативных и некреативных переключений социокоммуникативных регистров как значимого параметра конструирования дискурса в аспекте его лингвокреативности. Разработано само понятие социокоммуникативного регистра как социального подъязыка коммуникативного взаимодействия, выбор которого обусловлен прагматическими установками дискурса; установлена структура шкалы переключений регистров для анализируемых типов дискурса - кинодискурса и дискурса детской литературы. Предложен критерий разграничения креативных и некреативных переключений социокоммуникативных регистров в дискурсе, в качестве которого рассмотрен социокоммуникативный диссонанс, и установлены лингвокреативные технологии анализируемых переключений, представляющие собой три разновидности социокоммуникативного диссонанса или намеренного искажения в способах представления социальных ролей, коммуникативной ситуации или социокоммуникативного фор- 
мата дискурса, при котором актуализируется прагматическая установка исследуемых дискурсов - создание комического эффекта.

Контрастивное исследование лингвокреативных технологий переключения социокоммуникативных регистров в кинодискурсе и дискурсе детской литературы позволило сформулировать ряд важных выводов, расширяющих рамки понимания феномена лингвокреативности.

Во-первых, степень дискурсивно-специфического проявления лингвокреативности может быть оценена даже на единичных параметрах в условиях существования общей прагматической установки сопоставляемых дискурсов. В рассмотренном случае общая прагматическая установка дискурсов - создание эффекта комического - позволила определить особенности реализации социокоммуникативного диссонанса на уровнях социальных ролей, коммуникативной ситуации и социокоммуникативного формата дискурса. Во-вторых, численные проявления активности параметров в целом не имеют непосредственного отношения к лингвокреативным проявлениям этих параметров, так, более высокая активность параметра в целом может определяться другими дискурс-структурирующими факторами. Например, более высокая активность переключений регистра в дискурсе детской литературы может объясняться большей динамикой дискурса детской литературы в условиях отсутствия возможностей его полимодальной реализации. В-третьих, активность использования лингвокреативных технологий варьируется в разных дискурсах и позволяет выстроить дискурсы на общей шкале лингвокреативности с учетом а) абсолютной и б) относительной значимости каждого параметра. Так, параметр «переключение социокоммуникативных регистров» в кинодискурсе показал относительную активность в 2.14 раза выше, чем в дискурсе детской литературы (0.3 против 0.14), однако его абсолютное значение намного ниже: 17 примеров в кинодискурсе и 51 пример в дискурсе детской литературы.

Таким образом, полученные данные, в том числе статистические данные о характере распределения общего количества проявлений переключений регистров и количества их лингвокреативных проявлений, подтверждают наличие дискурсивно-специфических особенностей реализации переключения социокоммуникативных регистров. Это свидетельствует в пользу того, что показатели данного параметра могут использоваться как опорные при проведении контрастивно-дискурсивного анализа лингвокреативности рассматриваемых дискурсов. 
Применение разработанной методики в условиях расширения списка анализируемых параметров лингвокреативности дискурса позволит не только осуществлять оценку степени проявления лингвокреативности в уже существующих образцах дискурса, но и проводить прогностический экспертный анализ дискурса на предмет его потенциальной успешности.

\section{Библиография}

Виноградов, В. В. (1981). Проблемы русской стилистики. Высшая школа.

Дементьев, В. В. (2006). Непрямая коммуникация. Гнозис.

Демьянков, В. 3. (2011). Когнитивный диссонанс: Когниция языковая и внеязыковая. Когнитивные исследования языка, 2011(9), 33-40.

Жеребков, В. А. (1985). Коммуникативная модель как комплексный метазнак. Bonpocbl языкознания, 1985(6), 63-69.

Золотова, Г. А., Онипенко, Н. К., \& Сидорова, М. Ю. (1998). Коммуникативная грамматика русского языка. Издательство Московского государственного университета.

Зыкова, И. В. (2019). Code-switching как когнитивный прием реализации лингвокреативности в комедийном кинодискурсе. Когнитивные исследования языка, 2019(38), 216-228.

Зыкова, И. В., \& Киосе, М. И. (2020). Параметризация лингвистической креативности в междискурсивном аспекте: Кинодискурс vs. дискурс детской литературы. Bonpocbl когнитивной лингвистики, 2020(2), 26-40. https://doi.org/10.20916/1812-3228-2020-2-26-40

Ирисханова, О. К. (2016). Социальное искажение при конструировании событий и объектов природы: Галантные вороны и самоотверженные моллюски. Bonpocbl когнитивной лингвистики, 2016(46), 5-12.

Карасик, В. И. (2004). Языковой круг: Личность, концепты, дискурс (2nd ed.). Гнозис.

Киосе, М. И. (2020). Лингвистическая креативность моно- и полимодальной форм детской художественной литературы. Когнитивные исследования языка, 41(2), 1021-1026.

Ревзина, О. Г. (2014). Стилистическая система русского языка в динамическом аспекте. Язык, литература, культура, 2014(10), 23-36.

Шубин, Э.П. (1972). Языюковая коммуникаиия и обучение иностранным языкам. Просвещение.

Andersen, T. H., \& Boeriis, M. (2015). Multimodal register. In N. Nørgaard (Ed.), Key terms in multimodality: Definitions, issues, discussions. https://multimodalkeyterms.wordpress.com /multimodal-register/

Biber, D. (1995). Dimensions of register variation: A cross-linguistic comparison. Cambridge University Press. https://doi.org/10.1017/CBO9780511519871

Biber, D., \& Finegan, E. (Eds.). (1994). Sociolinguistic perspectives on register. Oxford University Press.

Dijk, van T. (1993). Principles of critical discourse analysis. Discourse and Society, 1993(4(2)), 249-283. https://doi.org/10.1177/0957926593004002006 
Eckert, P. (2018). Meaning and linguistic variation: The third wave in sociolinguistics. Cambridge University Press. https://doi.org/10.1017/9781316403242

Eggins, S., \& Martin, J. R. (1997). Genres and registers of discourse. In T. A. van Dijk (Ed.), Discourse and structure in progress (pp. 230-256). Sage Publications. https://doi.org /10.4135/9781446221884.n9

Firth, J. R. (1957). Personality and language in society. In J. R. Firth, Papers in linguistics: 1934-1951 (pp. 177-189). Oxford University Press.

Gibbs, R. W., \& Colston, H. L. (2020). Pragmatics always matters: An expanded vision of experimental pragmatics. Frontiers in Psychology, 2020(11), Article 1619. https://doi.org /10.3389/fpsyg.2020.01619

Giles, H., \& Ogay, T. (2007). Communication accommodation theory. In B. B. Whaley \& W. Samter (Eds.), Explaining communication: Contemporary theories and exemplars (pp. 293-310). Lawrence Erlbaum.

Gumperz, J. J. (1982). Discourse strategies. Cambridge University Press. https://doi.org/10.1017 /CBO9780511611834

Halliday, M. A. K. (1978). Language as social semiotic: The social interpretation of language and meaning. Edward Arnold.

Halliday, M. A. K., \& Hasan, R. (1980). Text and context: Aspects of language in a social-semiotic perspective. Sophia Linguistica: Working Papers in Linguistics, 1980(6), 4-91.

Jones, R. H. (Ed.). (2015). The Routledge handbook of language and creativity. Routledge. https:// doi.org/10.4324/9781315694566

Kiklewicz, A. (2017). Text fragmentation as a measure of persuasivity in the information services in Internet. Przeglad Wschodnioeuropejski, 2017(8(1)), 185-205. https://doi.org $/ 10.31648 /$ pw.3612

Leone, M. (2004). Religious conversion and identity: The semiotic analysis of texts. Routledge.

Matthiessen, C. (1993). Register in the round: Diversity in a unified theory of register analysis. In M. Ghadessy (Ed.), Register analysis: Theory and practice (pp. 221-292). Pinter.

Musolff, A. (2019). Creativity in metaphor interpretation. Russian Journal of Linguistics, 2019(23(1)), 23-39. https://doi.org/10.22363/2312-9182-2019-23-1-23-39

Nöth, W. (1987). Advertising: The frame message. In J. Umiker-Sebeok (Ed.), Marketing and semiotics: New directions in the study of signs for sale (pp. 279-292). De Gruyter Mouton. https://doi.org/10.1515/9783110853254.279

Oxford thesaurus of English (2006). Oxford University Press.

Quirk, R., Greenbaum, S., \& Leech, G. (1989). A comprehensive grammar of the English language. Longman.

Simpson, P. (Ed.). (2019). Style, rhetoric and creativity in language. John Benjamins. https:// doi.org/10.1075/lal.34

Ure, J., \& Ellis, J. (1977). Register in descriptive linguistics and linguistic sociology. In O. UribeVillegas (Ed.), Issues in Sociolinguistics (pp. 197-243). De Gruyter Mouton. https://doi.org /10.1515/9783110806687.197

Wodak, R. (1996). Disorders of discourse. Longman. 


\section{Bibliography (Transliteration)}

Andersen, T. H., \& Boeriis, M. (2015). Multimodal register. In N. Nørgaard (Ed.), Key terms in multimodality: Definitions, issues, discussions. https://multimodalkeyterms.wordpress.com /multimodal-register/

Biber, D. (1995). Dimensions of register variation: A cross-linguistic comparison. Cambridge University Press. https://doi.org/10.1017/CBO9780511519871

Biber, D., \& Finegan, E. (Eds.). (1994). Sociolinguistic perspectives on register. Oxford University Press.

Dement'ev, V. V. (2006). Nepriamaia kommunikatsiia. Gnozis.

Dem'iankov, V.Z. (2011). Kognitivnyı̆ dissonans: Kognitsiia iazykovaia i vneiazykovaia. Kognitivnye issledovaniia iazyka, 2011(9), 33-40.

Dijk, van T. (1993). Principles of critical discourse analysis. Discourse and Society, 1993(4(2)), 249-283. https://doi.org/10.1177/0957926593004002006

Eckert, P. (2018). Meaning and linguistic variation: The third wave in sociolinguistics. Cambridge University Press. https://doi.org/10.1017/9781316403242

Eggins, S., \& Martin, J. R. (1997). Genres and registers of discourse. In T. A.van Dijk (Ed.), Discourse and structure in progress (pp. 230-256). Sage Publications. https://doi.org /10.4135/9781446221884.n9

Firth, J. R. (1957). Personality and language in society. In J. R. Firth, Papers in linguistics: 1934-1951 (pp. 177-189). Oxford University Press.

Gibbs, R. W., \& Colston, H. L. (2020). Pragmatics always matters: An expanded vision of experimental pragmatics. Frontiers in Psychology, 2020(11), Article 1619. https://doi.org /10.3389/fpsyg.2020.01619

Giles, H., \& Ogay, T. (2007). Communication accommodation theory. In B. B. Whaley \& W. Samter (Eds.), Explaining communication: Contemporary theories and exemplars (pp. 293-310). Lawrence Erlbaum.

Gumperz, J. J. (1982). Discourse strategies. Cambridge University Press. https://doi.org/10.1017 /CBO9780511611834

Halliday, M. A. K. (1978). Language as social semiotic: The social interpretation of language and meaning. Edward Arnold.

Halliday, M. A. K., \& Hasan, R. (1980). Text and context: Aspects of language in a social-semiotic perspective. Sophia Linguistica: Working Papers in Linguistics, 1980(6), 4-91.

Iriskhanova, O. K. (2016). Sotsial'noe iskazhenie pri konstruirovanii sobytiǔ i ob"ektov prirody: Galantnye vorony i samootverzhennye moluski. Voprosy kognitivnoĭ lingvistiki, 2016(46), 5-12.

Jones, R. H. (Ed.). (2015). The Routledge handbook of language and creativity. Routledge. https:// doi.org/10.4324/9781315694566

Karasik, V. I. (2004). IAzykovoĭ krug: Lichnost', kontsepty, diskurs (2nd ed.). Gnozis.

Kiklewicz, A. (2017). Text fragmentation as a measure of persuasivity in the information services in Internet. Przeglad Wschodnioeuropejski, 2017(8(1)), 185-205. https://doi.org /10.31648/pw.3612 
Kiose, M. I. (2020). Lingvisticheskaia kreativnost' mono- i polimodal'noŭ form detskoŭ khudozhestvennoĭ literatury. Kognitivnye issledovaniia iazyka, 2020(2(41)), 1021-1026.

Leone, M. (2004). Religious conversion and identity: The semiotic analysis of texts. Routledge.

Matthiessen, C. (1993). Register in the round: Diversity in a unified theory of register analysis. In M. Ghadessy (Ed.), Register analysis: Theory and practice (pp. 221-292). Pinter.

Musolff, A. (2019). Creativity in metaphor interpretation. Russian Journal of Linguistics, 2019(23(1)), 23-39. https://doi.org/10.22363/2312-9182-2019-23-1-23-39

Nöth, W. (1987). Advertising: The frame message. In J. Umiker-Sebeok (Ed.), Marketing and semiotics: New directions in the study of signs for sale (pp. 279-292). De Gruyter Mouton. https://doi.org/10.1515/9783110853254.279

Oxford thesaurus of English (2006). Oxford University Press.

Quirk, R., Greenbaum, S., \& Leech, G. (1989). A comprehensive grammar of the English language. Longman.

Revzina, O. G. (2014). Stilisticheskaia sistema russkogo iazyka v dinamicheskom aspekte. IAzyk, literatura, kul'tura, 2014(10), 23-36.

Shubin, E். P. (1972). IAzykovaia kommunikatsiia i obuchenie inostrannym iazykam. Prosveshchenie.

Simpson, P. (Ed.). (2019). Style, rhetoric and creativity in language. John Benjamins. https:// doi.org/10.1075/lal.34

Ure, J., \& Ellis, J. (1977). Register in descriptive linguistics and linguistic sociology. In O. UribeVillegas (Ed.), Issues in Sociolinguistics (pp. 197-243). De Gruyter Mouton. https://doi.org /10.1515/9783110806687.197

Vinogradov, V. V. (1981). Problemy russkoŭ stilistiki. Vysshaia shkola.

Wodak, R. (1996). Disorders of discourse. Longman.

Zherebkov, V. A. (1985). Kommunikativnaia model' kak kompleksnyı̆ metaznak. Voprosy iazykoznaniia, 1985(6), 63-69.

Zolotova, G. A., Onipenko, N. K., \& Sidorova, M. IU. (1998). Kommunikativnaia grammatika russkogo iazyka. Izdatel'stvo Moskovskogo gosudarstvennogo universiteta.

Zykova, I. V. (2019). Code-switching kak kognitivnyı̆ priem realizatsii lingvokreativnosti v komediŭnom kinodiskurse. Kognitivnye issledovaniia iazyka, 2019(38), 216-228.

Zykova, I. V., \& Kiose, M. I. (2020). Parametrizatsiia lingvisticheskoĭ kreativnosti v mezhdiskursivnom aspekte: Kinodiskurs vs. diskurs detskoŭ literatury. Voprosy kognitivnoŭ lingvistiki, 2020(2), 26-40. https://doi.org/10.20916/1812-3228-2020-2-26-40 


\title{
Socio-Communicative Register Switching as a Parameter of Linguistic Creativity: Cinematic Discourse vs Discourse of Children's Literature
}

\author{
Summary
}

This study is devoted to the discourse specificity of socio-communicative register switching as a parameter of linguistic creativity. A contrastive analysis of cinematic discourse and discourse of children's literature helped to define the characteristics of register and the criteria of socio-communicative dissonance, which served to distinguish between creative and non-creative use of register switching. The study identifies three creative techniques of register switching, demonstrating socio-communicative dissonance (as intentional pragmatic distortion) in social roles, communicative situations and socio-communicative discourse format. The results indicate the parametric variance of activity in the discourse types under consideration, with higher values of both creative and non-creative techniques in the discourse of children's literature, and higher relative values of creative vs non-creative use of socio-communicative register switching in cinematic discourse. The results also demonstrate the efficiency of the parametric method in the study of linguistic creativity.

\section{Przełączanie rejestrów socjokomunikatywnych jako parametr kreatywności lingwistycznej. Dyskurs kinowy vs dyskurs literatury dziecięcej}

\section{Streszczenie}

Przedmiotem artykułu jest dyskursowa specyfika przełączania rejestrów socjokomunikatywnych w roli parametru kreatywności lingwistycznej. Konfrontatywna analiza dyskursu uwzględniająca dyskurs kinowy i dyskurs literatury dziecięcej pomogła określić charakterystykę rejestrów oraz kryteria 
dysonansu socjokomunikatywnego, co posłużyło do wskazania różnic pomiędzy kreatywnym a niekreatywnym użyciem przełączania rejestrów. Stwierdzono istnienie trzech kreatywnych technik przełączania rejestrów, wprowadzających dysonans socjokomunikatywny (będący celowym zniekształceniem pragmatycznym) w zakresie ról społecznych, sytuacji komunikacyjnych i formatu dyskursu socjokomunikatywnego. Rezultaty pokazują zmienność aktywności parametrowej konfrontowanych typów dyskursu, z wyższymi wartościami zarówno kreatywnych, jak i niekreatywnych technik w dyskursie literatury dziecięcej, a zarazem wyższymi relatywnymi wartościami wykorzystania przełączania kreatywnych rejestrów socjokomunikatywnych w dyskursie kinowym. Jednocześnie rezultaty dowodzą skuteczności metody parametrycznej w badaniach nad kreatywnością lingwistyczną.

Keywords: linguistic creativity; socio-communicative register; socio-communicative dissonance; cinematic discourse; discourse of children's literature; parametrisation

Słowa kluczowe: kreatywność językowa; rejestr socjokomunikatywny; dysonans socjokomunikatywny; dyskurs kinowy; dyskurs literatury dziecięcej; parametryzacja

(1) Irina V.Zykova, Institute of Linguistics, Russian Academy of Sciences, Moscow, Russia

ORCID: https://orcid.org/0000-0002-0430-7769

Correspondence: zykova_iv@mail.ru

(2) Maria I. Kiose, Moscow State Linguistic University, Moscow, Russia

ORCID: https://orcid.org/0000-0001-7215-0604

Correspondence: maria_kiose@mail.ru

Authors' contribution: Concept of the study: first author; data analyses: first and second author; writing the manuscript: first and second author.

The preparation of this article was financed by a grant from the Russian Science Foundation (Project No. 19-18-00040) and carried out at the Institute of Linguistics of the Russian Academy of Sciences.

Competing interests: The authors have declared that they have no competing interests.

Publication history: Received: 2020-09-10; Accepted: 2021-02-01; Published: 2021-11-28 